\title{
Capital Structure and Related Financial Strategy for Circular Economy Corporate
}

\author{
Chang Shu \\ Faculty of civil engineering \\ Kunming University of Science and Techonology, \\ Kunming, China \\ sshu22@tom.com
}

\begin{abstract}
This paper aims to explore the features of capital structure and related financial strategy of circular economy corporates as well as their inter-relationships. The methodology adopted is obvious of some inventively combined methods, since previous researches have seldom studied this field and few conclusions and results can be learned from. Circular economy corporate distinguish from other normal corporates as to financial characteristics and strategy, thus it's worthwhile to take endeavors to do related research. This research focuses on the relationship between multi independent variables and multi dependent variables. PCA helps to simplify the process by converting a set of observations of possibly correlated variables into a set of values of linearly uncorrelated variables called principal components. Andin the case of limited samples information, or even when the sample number is less than the number of variables, the stepwise regression is usually adopted to do the analysis. Because the financial strategy is rather complicated and varies by different stages, we conclude that two independent variables will directly impact the strategy and need extra attention in strategy decision-making.
\end{abstract}

Keywords: Financial strategy, Capital structure, PCA, small-sample stepwise regression

\section{Introduction}

The theory of capital structure if based on microeconomics with the premise of rational economic human being and expressed by strict mathematic form, while the interrelationship between the capital structure and corporate financial strategy is seldom studied and the relevant studies and literature are few and far between. For a rather long time, corporate strategy theory and corporate financial theory have been focused on their respective field, for example, the corporatestrategy theory addresses more on strategic management while ignoring the strategic study; the corporate financial theory pays more attention on capital market and capital operation but ignoring strategic management methods, which results in the dismatch of financial theory and corporate strategy theory and fails to meet the needs of corporate strategy. Although the interrelationship has seldom been studied but they do have close relationship in fact. (Na pengjie, 2008)

The relationship between industry characteristics and capital structure: Harris and Raviv (1991) found that the capital structure of enterprises in the same industry is similar, and the capital structure of different industries is different, and has time stability. Medicine, equipment, electronics, food industries have lower debt ratio; paper, textile, steel, aviation, cement industries have higher debt ratio; industries under government regulations, such as telephone, electricity, gasoline and other utilities and aviation have the highest debt ratio. While MacKay and Phillips (2004) in the research of 
the relationship between financing decision-making and product market decision-making found out that the industry factor can only explain $13 \%$ of the capital structure difference, and the enterprise specific factors can explain $54 \%$ of the differences, that is, the intra industry capital structure difference is greater than the inter industry's capital structure difference. So, capital structure is closely related to the status of the enterprise and the competitive situation.(Zhu kaixi, 2011). Zhong Tianli, Fan Yu (2004) found through inspections that radical phenomenon lying in China's capital market: the more intense competition in the product market, the higher the company's financial leverage.
II . CAPITAL STRUCTURE AND FINANCIAL STRATEGY

\subsection{Influential elements of capital structure in company}

The comprehensive literary result of Harris Milton, Autur Raviv,etc. and domestic research of Zhengfei Lu, Xin yu(1998), Zhang zebin, Zhu shaoxing(2000), Xiao Zuoping(2003), Huang guimin, Song min (2000), Du liwen, 2011shows that the influential factors and their factor measurement results are company size $(+)$, growth (-), profitability(-), rate (+), TANG (+), Non debt tax shield (SNDT) (-), managerial ownership, capital structure (+/-), of which “+” means positive correlation, “-”means negative relation. In summary, the indexes use to discribe the project are concluded as follows:

TABLE 1 INDEX DESCRIPTION AND INDEX LIST

\begin{tabular}{|c|c|c|}
\hline Index code & index name & index description \\
\hline $\mathrm{X} 1$ & main business income & main business income of the year \\
\hline $\mathrm{X} 2$ & sales of natural logarithm & Ln (total sales volume of this year) \\
\hline X3 & main business revenue growth rate & MOIGt=（MOIt-MOIt-1）/MOIt-1*100\% \\
\hline $\mathrm{X} 4$ & total asset growth rate & TAGt $=($ TAt-TAt-1)/TAt $-1 * 100 \%$ \\
\hline $\mathrm{X} 5$ & current ratio & current assets in proportion of current liabilities \\
\hline X6 & return on assets & net profit / total assets \\
\hline $\mathrm{X} 7$ & net return on net assets & net profits/ shareholders' equity \\
\hline $\mathrm{X} 8$ & main business profit ratio & main business profit / main business income \\
\hline X9 & $\begin{array}{l}\text { asset guarantee value (positive } \\
\text { indicator) }\end{array}$ & (inventory + fixed assets) $/$ total assets \\
\hline $\mathrm{X} 10$ & $\begin{array}{l}\text { asset guarantee value (negative } \\
\text { indicator) }\end{array}$ & intangible assets / total assets \\
\hline $\mathrm{X} 11$ & non-debt tax shield & depreciation/total assets \\
\hline $\mathrm{X} 12$ & asset structure & fixed assets / total assets \\
\hline
\end{tabular}

\subsection{Financial strategy}

As to the relationship between enterprise life cycle and the capital structure, the representative theory is the financial strategy matrix proposed by Hawaweini and Vieri.Hawawini and Vieri in the monograph of enterprise value creation distinct value creation (return on invested capital rate ROIC- capital cost rate WACC) and cash deficiency (sales growth rate Gsale- sustainable growth rate (SGR)) respectively as vertical and horizontal axis of a matrix, the matrix is called financial strategy matrix, providing a good analysis tool for evaluation of the financial strategy. 
In the fourth edition of the two edition of the book, the new financial strategy matrix replacethe old version. This new financial strategy matrix is as follows:

TABLE 2 NEW FINANCIAL STRATEGY- RETURN ON INVESTMENT - CAPITAL COST RATIO

\begin{tabular}{|c|c|c|}
\hline $\begin{array}{l}\text { Sales growth rate } \\
\text { - sustainable growth rate }<0\end{array}$ & $\begin{array}{l}\text { Sales growth rate } \\
\text { - sustainable growth rate }>0\end{array}$ & \\
\hline Second stage & First stage & \multirow{3}{*}{$\begin{array}{c}\text { Return on investment - capital cost } \\
\text { ratio }>0 E V A>0\end{array}$} \\
\hline Robust financial strategy & Expanding financial strategy & \\
\hline Value creator with cash surplus & Value creator with cash shortage & \\
\hline Third stage & Fourth stage & \multirow{3}{*}{$\begin{array}{c}\text { Return on investment - capital cost } \\
\text { ratio }<0 E V A<0\end{array}$} \\
\hline Shrinking financial strategy & Deep contracting financial strategy & \\
\hline Value destroyer with cash surplus & Value destroyer with cash shortage & \\
\hline
\end{tabular}

The new financial matrix is updated by introduction of EVA values.Enterprise $\mathrm{A}$ is a circular economy demonstration enterprise. We analyze different status of the enterprise within a span of five years' time. Enterprise capital return on investment rate, return on capital (return on Invested capital) refers to the ratio of investment and / or use of funds and related returns (usually returns in form of obtained interest and / or shared profits). It is used to measure the effect fund investment. Capital return is a lagging indicator, that is, it reflected the company's historical performance. The cost of funds used for financing a business. Cost of capital depends on the mode of financing used - it refers to the cost of equity if the business is financed solely through equity, or to the cost of debt if it is According to the conversion formula, the short-term interest rate is $r=(1+4.92 \%)(1 / 6)$ $-1=0.8 \%$

The conclusion of the above is that enterprise $\mathrm{A}$ is of the first quadrant of the value-creator cash shortage. According to the conclusions of the research on the sustainable development of small and medium sized company, the research object of 60 small listing Corporation, 46 of the listing Corporations are in the first quadrant, accounting for $76.67 \%$ of the total, 1 in the second quadrant, accounting for $1.67 \%$ of the total, 2 in the 3rd quadrant, accounting for 3.33\%, 11 in the fourth quadrant, counting for 18.33\%. (Wang Jing, 2014) financed solely through debt. Since the cost of capital represents a hurdle rate that a company must overcome before it can generate value, it is extensively used in the capital budgeting process to determine whether the company should proceed with a project.

TABLE 32015 ISSUE OF NATIONAL DEBT

\begin{tabular}{|l|l|l|l|l|}
\hline $\begin{array}{l}\text { National } \\
\text { debt }\end{array}$ & $\begin{array}{l}\text { maturit } \\
\text { y period } \\
\text { (year) }\end{array}$ & $\begin{array}{l}\text { Nominal } \\
\text { interest } \\
\text { rate }\end{array}$ & Issue date & $\begin{array}{l}\text { Payment } \\
\text { method }\end{array}$ \\
\hline $\begin{array}{l}\text { Documen } \\
\text { t type }\end{array}$ & 3 & $4.92 \%$ & 10 th & $\begin{array}{l}\text { Debt } \\
\text { service } \\
\text { due }\end{array}$ \\
\cline { 2 - 3 } & 5 & $5.32 \%$ & March & Annual \\
Electroni & 3 & $4.92 \%$ & $\begin{array}{l}10 \text { th } \\
\text { April }\end{array}$ & interest \\
\hline
\end{tabular}

\section{METHODOLOGY}

Enterprise A which develops well in circular economy obviously distinguishesfrom the general large resource-based enterprises in the financial strategy category. The first quadrant enterprise can create value for the shareholders, but their operating cash flow is not enough to support the sales growth, unavoidably encountering a shortage of cash. And the large resource-based enterprises are generally in the form of value-destroyer, the preferred strategy is to improve the return on investment capital by two ways: (1) to improve the after-tax operating 
profit margin; (2) improve asset turnover rate. In the same time, if the debt ratio is not compatible, it can be adjusted to reduce the average cost of capital. If the enterprise cannot improve the return on investment capital or reduce the cost of capital, it should be sold.

Capital structure theory is an important aspect of corporate financial theory research and core of financial theory. From Modigliani and Miller (1958) to create the modern capital structure theory, the capital structure theory has been developed for more than 40 years. MM gives the proposition that the value of enterprise is not related to capital structure. Although in theory circle, scholars seldom study the interaction between corporate strategy and capital structure, but in fact, there is a close relationship between the two. When an enterprise implements an important strategy to invest in a strategic asset, it needs to carry out the relevant financing decisions, and different financing or say capital structure determines the different capital costs, and also determines the different cash flow, and also produces a different contract relations and control issues.

In recent years, due to the need of development of relevant theories and realities, the capital structure of enterprise gains more and more attention in the research of enterprise strategy. Bettis (1983) thinks that modern finance theory and strategic management are based on different paradigms, which come to different conclusions, but the comprehensive research can resolve the contradiction. Kochhar (1997) combined the strategic asset and capital structure to study the company's strategic management and corporate

TABLE 4 KMO AND BARTLETT'S TEST

\begin{tabular}{ll|l}
\hline Kaiser-Meyer-Olkin measure of Sampling & .630 \\
Adequacy. & & \\
Bartlett's Approx Chi-square & 41.654 \\
Test of $\mathrm{df}$ & 10 \\
Sphericitty $\quad$ Sig. & .000
\end{tabular}

performance, and the integration of the two disciplines, and proposed a framework afterwards. In short, corporate financing decision-making and strategic management as the two important management activities of the enterprise, there is a certain connection between the two, and is of important significance for the enterprise to obtain sustainable competitive advantage and excellent performance. (Na Pengjie, product market, capital structure and corporate strategy)

\section{IV.RESULTS AND DISCUSSION}

\subsection{Principalcomponent analysis}

Principal component analysis (PCA) is a statistical procedure that uses an orthogonal transformation to convert a set of observations of possibly correlated variables into a set of values of linearly uncorrelated variables called principal components. The number of principal components is less than or equal to the number of original variables.

Consider a data matrix, $\mathrm{X}$, with column-wise zero empirical mean (the sample mean of each column has been shifted to zero), where each of the $n$ rows represents a different repetition of the experiment, and each of the $\mathrm{p}$ columns gives a particular kind of datum (say, the results from a particular sensor).

Mathematically, the transformation is defined by a set of p-dimensional vectors of weights or loadings that map each row vector of $\mathrm{X}$ to a new vector of principal component scores, given by in such a way that the individual variables of $t$ considered over the data set successively inherit the maximum possible variance from $\mathrm{x}$, with each loading vector $\mathrm{w}$ constrained to be a unit vector.

Based on the above output the $\mathrm{KMO}=0.630$, which is more than the selection value of 0.6. This shows that the degree of common variables is quite high, therefore factor analysis can be conducted. 
Based on the output above, all the variables have the communalities of morethan0.5, so all these variables share the portion of the variance that contribute to the common factors. Except for the variable "capital cost ratio" and "sales growth rate", the common component almost cover at least $80 \%$ of information of the original data.

\begin{tabular}{|l|l|l|}
\hline \multicolumn{2}{c|}{ TABLE 5 } & OMMUNALITIES \\
\hline & Initial & Extraction \\
\hline Return on investment & 1.000 & .937 \\
Capital cost ratio & 1.000 & .795 \\
Sales growth rate & 1.000 & .677 \\
Sustainable growth & 1.000 & .937 \\
rate & & .954 \\
EVA & 1.000 & \\
\hline
\end{tabular}

TABle 6 TOTAL VARIANCE EXPlained

\begin{tabular}{|l|l|l|l|l|l|l|}
\hline \multirow{2}{*}{$\begin{array}{l}\text { Compone } \\
\text { nt }\end{array}$} & \multicolumn{4}{|l|}{ Initial Eigenvalues } & \multicolumn{2}{l|}{ Extraction Sums of Squared Loadings } \\
\cline { 2 - 7 } & Total & \% of Variance & Cumulative \% & Total & \% of Variance & Cumulative \% \\
\hline 1 & 3.272 & 65.447 & 65.447 & 3.272 & 65.447 & 65.447 \\
2 & 1.028 & 20.563 & 86.009 & 1.028 & 20.563 & 86.009 \\
3 & .632 & 12.643 & 98.652 & & & \\
4 & .053 & 1.054 & 99.706 & & & \\
5 & .015 & .294 & 100.000 & & & \\
\hline
\end{tabular}

Extraction Method: Principal Component Analysis.

From the above output, the variance of the first two factors y1, y2 account for $86 \%$ of all the variance, thus we choose y1 as the 1 st common factor and y2 as the 2nd common factor, and the variance of these two factors account for $86 \%$ of all the variance, that is they basically reserve the information of the original indicators. Theseindicators are transformed into 2 new indicators, functioning the role of dimensionality reduction.

\subsection{Stepwise regression:}

In the case of limited samples information, or even when the sample number is less than the number of variables, the stepwise regression is usually adopted to do the analysis. In statistics, stepwise regression includes regression models in which the choice of predictive variables is carried out by an automatic procedure. Usually, this takes the form of a sequence of F-tests or t-tests, but other techniques are possible, such as adjusted R-square, Akaike information criterion,
Bayesian information criterion, Mallows's Cp, PRESS, or false discovery rate.The frequent practice of fitting the final selected model is followed by reporting estimates and confidence intervals without adjusting them to take the model building process into account, and this has led to calls to stop using stepwise model building altogether or to at least make sure model uncertainty is correctly reflected.

Stepwise regression procedures are used in data mining, but are controversial. In this research, we examine the relationship between the capital structure influential variables and the financial strategy influential variables, which is a many to many regression model. After the simplification of model by adopting principal analysis method, the relationship is transformed into a one to many model, that is 12 independentvariables $\mathrm{Xi}$ and one dependent variable Y. Limited by the company condition, we only found 10 batches of financial variables in different time. Due to this small sample, we use stepwise regression, 
dividing the 12 independent variables into 4 batches and conduct the analysis in 2 phases. The original data is transformed into a logarithmic transformation, at the same significant level of $\mathrm{F}$ value with Entry of 3.84, Removal of 2.71. And the result is shown in the table:

TABLE 7 StePWISE REgRESSION ANALYSIS RESUlT ON 12 VARIABLES (USE F VALUE ENTRY:3.84, REMOVAL: 2.71, N=10)

\begin{tabular}{|c|c|c|c|c|c|c|}
\hline Phase & Batch & Variables & $\begin{array}{c}\text { Selected } \\
\text { variables }\end{array}$ & $\begin{array}{c}\text { Adjusted R } \\
\text { square }\end{array}$ & Sig. & $F$ \\
\hline & 1 & $\mathrm{X} 1, \mathrm{X} 2, \mathrm{X} 3$ & X3 & .292 & .107 & 3.300 \\
\hline & 2 & $\mathrm{X} 4, \mathrm{X} 5, \mathrm{X} 6$ & X6 & .875 & .000 & 55.821 \\
\hline 1 & 3 & X7,X8,X9 & $\mathrm{X} 8$ & .662 & .004 & 15.682 \\
\hline & $4 *$ & $\mathrm{X} 10, \mathrm{X} 11, \mathrm{X} 12$ & & & & \\
\hline 2 & 1 & X3,X6,X8 & $\mathrm{X} 6, \mathrm{X} 8$ & .927 & .060 & 44.372 \\
\hline
\end{tabular}

$\square$ indicates that limited by F value, there is no entry of any variables

Among which, the selected independent variables in the 2nd phase is $\mathrm{X} 3, \mathrm{X} 6$ and $\mathrm{X} 8$, and their corresponding partial correlation coefficients are $\mathrm{R} 3=0.54, \mathrm{R} 6=0.935, \mathrm{R} 8=0.814$. It's obvious that return on assets and main business profit ratio act as the most prominent elements to the corporate financial strategy, following by the X3 main business revenue growth rate.

TABLE 8 CORRELATIONS

\begin{tabular}{|c|c|c|c|c|c|}
\hline \multirow{4}{*}{$\begin{array}{c}\text { Pearson } \\
\text { Correlation }\end{array}$} & $\begin{array}{c}\text { main business revenue } \\
\text { growth rate }\end{array}$ & 1.000 & .349 & .313 & .540 \\
\hline & return on assets & .349 & 1.000 & .796 & .935 \\
\hline & main business profit ratio & .313 & .796 & 1.000 & .814 \\
\hline & financial strategy & .540 & .935 & .814 & 1.000 \\
\hline \multirow{4}{*}{ Sig. (1-tailed) } & $\begin{array}{c}\text { main business revenue } \\
\text { growth rate }\end{array}$ & & .162 & .189 & .053 \\
\hline & return on assets & .162 & & .003 & .000 \\
\hline & main business profit ratio & .189 & .003 & & .002 \\
\hline & financial strategy & .053 & .000 & .002 & \\
\hline
\end{tabular}

We finally get the regression equation: $y=1250950.570+0.85 \times 6+0.244 \times 8$. Through the above stages and the optical selection of stepwise regression analysis, 2 were selected from 16 independent variablescorrelated respectively to capital structure and financial strategy through repeated screening. Through the different development phases, return on assets and main business profit ratio have important value in the company growth financial strategy. And this shows us how to make financial decisions during different corporate development phases and make decisions.

\section{V.CONCLUSIONS}

In this paper, we try to illustrate how the capital structure elements will influence the corporate financial strategy. PCA successfully transform the multiple dependent variable into one main component and simplifies the mathematical operation process.

The key of small sample stepwise regression method is to divide the correlation matrix of the total $\mathrm{R}(\mathrm{p}+1) \mathrm{x}(\mathrm{p}+1)$ into a number of a plurality of master correlation matrix in correspondence, then to each of the master correlation matrix 
variable transformation matrix is introduced or removed, and then the introduced number of $\mathrm{K}$ variables will constitute new master correlation matrix $\mathrm{R}(\mathrm{k}+1) \times(\mathrm{K}+1)$. (Xiao Xiaonan, 2001)Obviously, this correlation matrix is a sub array of $\mathrm{R}(\mathrm{p}+1) \times(\mathrm{p}+1)$. Based on the $\mathrm{R}(\mathrm{k}+1) \times(\mathrm{K}+1)$ above steps can be conducted repeatedly, finally 3 factors which are the most significant to the dependent variables are induced. Their correlation coefficient constitute a sub array $\mathrm{R}(\mathrm{m})(\mathrm{s}+1) \times(\mathrm{s}+1)$ of $\mathrm{R}(\mathrm{p}+1) \times(\mathrm{p}+1)$, of which $m$ is the number of stages. $R(p+1) x$ $(\mathrm{p}+1)$ a new correlation matrix, which is made up of non-significant factors to the dependent variable, can be used in the pre selection. In another word, during the stepwise regression process, this is similar to result where the corresponding (P-S) variables of the array $\mathrm{R}(\mathrm{p}+1) \times(\mathrm{p}+1)$ are introduced by evenly number of times and in the exchange of the result is eliminated. In short, the correlation matrix $\mathrm{R}(\mathrm{m})$ $(\mathrm{s}+1) \times(\mathrm{s}+1)$ contains most of the information about the significant factor that contributes to they. Therefore, the small sample and the partial regression analysis conducted in stages and batches can reflect the overall situation.

\section{REFERENCES}

[1] Aghion, P., Dewatripont, M., Rey, P., 2000. Agency Costs, Firm Behavior and the Nature of Competition, mimeo,IDEI, Universit'e de Toulouse.

[2]Cleary, S., Povel, P., Raith, M., 2003. The U-shaped Investment Curve: Theory and Evidence, mimeo, St. Mary's University, University of Minnesota and University of Rochester.

[3] Campello M..Debt financing: Does it boost or hurt firm performance in product markets[J].Journal of Financial Economics,2006, Vol.82.

[4] DeMarzo, P.M., Fishman, M.J., 2000. Optimal Long-Term Financial Contracting with Privately Observed CashFlows, mimeo, UC
Berkeley and Northwestern University.

[5] Deng Jianqin, Zhu wuxiang. Product market competition, stock right constraints and financial radical behavior, 2006(3)

[6] Flannery,M.,Rangan,K. Partial adjustment toward target capital structures[J]. Journal of Financial Economics, 2006(79): 469- 506

[7] Huang guoliang. Study on the managerial entrenchment, capital structure and corporate performance, 2009(6).

[8] Jin minghui.The research of enterprises' financial management theory based on circular economy, 2008,June.

[9]JoDewulf,HermanVanLangenhove.Integrating iindustrialEologyprinciPlesintoasetofEnvironmen talSustainabilityIndieatorsforTechnologyAssess ment.Resourees,ConservationandReeyeling.2005 $, 43: 419$ - 43

[10]Kang Eugene , Zardkoohi Asghar. Board Leadership Structure and Firm Performance[J]. Corporate Governance ,2005, 13 (6) : 785-799.

[11]Kayhan A., Titman S.. Firms' histories and their capital structure. Journal of Financial Economics, 2007:83

[12]Khanna, N., Tice, S., 2000. Strategic responses of incumbents to new entry: the effect of ownership structure, capital structure, and focus. Review of Financial Studies 13, 749-779.

[13]Kale,J,R., Shahrur,H.. Corporate capital structure and the characteristics of suppliers and customers[J].Financial Ecomonics,2007, Vol.83. [14]Kwangmin Park, 2013. Capital structure, free cash flow, diversification and firm performance, A holistic analysis. The International Journal of Hospitality Management 33(2013) 51-63

[15]Li jinke. The empirical study on capital structure and management performance of the steel industry companies in China. 2010.12.

[16]Liu Zhibiao, Jingfuxiu, Luerpo. Capital structure and competition intensity of product market. Economic Study. 2003(7).

[17]MacKay,P., $\quad$ Phillips,G.M..How Does Industry Affect FirmFinancial Structure [J]. Review of financial studies, 2005, Vol.18, (4). 
[18]MiehaelR.King,ErieSantor.FamilyValues:O wnershiPstructure,Performance and capital structure of Canadian firms. Journal of Banking and Finanee,2008,11(32):2423 - 2432.

[19]Na Pengjie, Na Chaohong, Leng Pingsheng, 2008. Product market, capital structure and corporate strategy. Social Science in Yunnan No3. 2008.

[20]Paul Povel, Michael Raith, 2004.Fincnail constraints and product market competition: ex ante vs.ex post incentives. International Journal of Industrial Organization 22(2004) 917-949

[21]Ross, S., 1977. The determination of financial structure: the incentive-signalingapproach. The Bell Journal of Economics 8, 23-40.

[22]Titman S., Tsyplakov S.. A Dynamic Model of Optimal Capital Structure. Review of Finance, 2007:3

[23]Wang Goosing, 2010. Study on the Choice Financial Behavior of Creating-value and Cash-shortage Enterprises.

[24]Yueh-hsiang Lin, Shing-yang $\mathrm{Hu}$, Ming-shen Chen.Testing pecking order prediction from the viewpoint ofmanagerial optimism : Some empirical evidence from Taiwan.Journal of Political Economy， 2004:12 